\title{
Occurrence of Chloeia flava pulchella Baird, 1868, from Off Junglighat, South Andaman, India
}

\author{
K. K. Dil Baseer Sabith1, V. Shivashankar², G. Narshimulu³, P. M. Mohan ${ }^{*}$ \\ ${ }^{1}$ Department of Ocean Studies and Marine Biology, Pondicherry University off Campus, Brookshabad, Port Blair, Andaman and \\ Nicobar Islands, India \\ ${ }^{2}$ Department of Coastal Disaster Management, Pondicherry University off Campus, Brookshabad, Port Blair, Andaman and \\ Nicobar Islands, India \\ ${ }^{3}$ Jawaharlal Nehru Rajkeya Mahavidyalaya, Port Blair, Andaman and Nicobar Islands, India \\ Email: *pmmnpu@rediffmail.com, *pmmtu@yahoo.com
}

How to cite this paper: Sabith, K.K.D.B., Shivashankar, V., Narshimulu, G. and Mohan, P.M. (2022) Occurrence of Chloeia flava pulchella Baird, 1868, from Off Junglighat, South Andaman, India. Open Journal of Marine Science, 12, 19-25.

https://doi.org/10.4236/ojms.2022.121002

Received: September 14, 2021

Accepted: January 17, 2022

Published: January 20, 2022

Copyright $\odot 2022$ by author(s) and Scientific Research Publishing Inc. This work is licensed under the Creative Commons Attribution International License (CC BY 4.0).

http://creativecommons.org/licenses/by/4.0/

\begin{abstract}
Fire-worms from the family Amphinomidae Lamark, 1818, act as a predator, scavenger and sedimentivores, in nearshore waters. This family has 146 valid species among them 18 numbers reported from Indian marine environment and 11 reported from the Andaman waters. Among this family, genus Choleia Lamark. 1818, reported 4 species and 1 subspecies from the Andaman waters. Among these the species Chloeia flava pulchella Baird, 1868 was reported by Tampi and Rangarajan, 1964, but no detailed species description was found for this species. During the studies on continuous monitoring of the environmental parameter of nearshore waters of off South Andaman region, a specimen of Chloeia flava pulchella Baird, 1868, was collected. Later the cursory analysis for this specimen identification was revealed that the detailed description of this species found in this region was not available in the literature. So, the detailed taxonomic description was developed and presented in this article.
\end{abstract}

\section{Keywords}

Fire-Worm, Chloeia flava pulchella, Near Shore, Junglighat, South Andaman, Andaman Islands

\section{Introduction}

The fire-worms are belonging to family Amphinomidae Lamark, 1818, commonly seen in intertidal areas and rich in coral reef environments [1]. They are known for their scary morphological features and the blazing sensation they cause with their calcareous setae [2]. Fire-worms act as a predator, scavenger and sedimentivores in different environment [3] [4]. They can be recognized with some of the 
features like numerous calcified setae, caruncle, and tetraneural cods [5]. The family Amphinomidae Lamark, 1818, has consisting of 146 valid species from 22 genus under 2 subfamily [6]. There are 18 species that belong to this family that are reported from the Indian subcontinent, of which 11 are reported from Andaman Island [7]. From the total of 27 valid species present under the Genus Chloeia Lamark, 1818, 7 species and 1 subspecies have been recorded from Indian Coast. Out of which 4 species and one subspecies are reported from Andaman and Nicobar Islands, Chloeia amphora Horst, 1910, Chloeia fava (Pallas, 1766), Chloeia flava pulchella Baird, 1868, Chloeia fusca McIntosh, 1885, Chloeia parva Baird, 1868.

After a vague description of Chloeia flava pulchella Baird, 1868 by Tampi and Rangarajan [8], there is no seminal work describing the species from Andaman as well as from India. Further, cursory analysis of identification of this species was found that there was no detailed description of this species available in the literature, for the specimen's present in this region. So, an attempt has been made to provide a detailed description for the species collected during the routine environmental monitoring studies.

\section{Study Area}

Andaman and Nicobar Islands situated in Bay of Bengal, with a cluster of islands and formed as an archipelago. These islands are divided in two major groups of Islands, i.e. Andaman and Nicobar groups of Island, based on the separation by the huge amount of marine water column, designated as the Ten Degree Channel. The eastern part of these islands waters are designated as Andaman Sea and western side of sea waters called as Bay of Bengal. The bottom topography of the Andaman Sea basin suggested comparatively elevated platform than Bay of Bengal depth, so the environment of this Andaman Sea considered as a unique and mixing biota very minimal with other parts of the oceans. The sample collected from the location, Off Junglighat, has been situated in western side of Port Blair city, which has been considered as a major fishing harbor (Figure 1).

\section{Materials and Methods}

\subsection{Materials}

The sediment samples were collected during the monthly study for environmental evaluation of the nearshore environment. The sediment samples collected during the process through the Van Veen grab sampler. The collected samples were preserved in $10 \%$ formalin immediately and anlaysed in the laboratory on subsequent days. The samples were collected on $24^{\text {th }}$ December 2020.

\subsection{Methods}

The sediment sample collected was wet sieved using 500 micron ASTM sieve. During the process, the polycheta was found and collected using the forceps and 


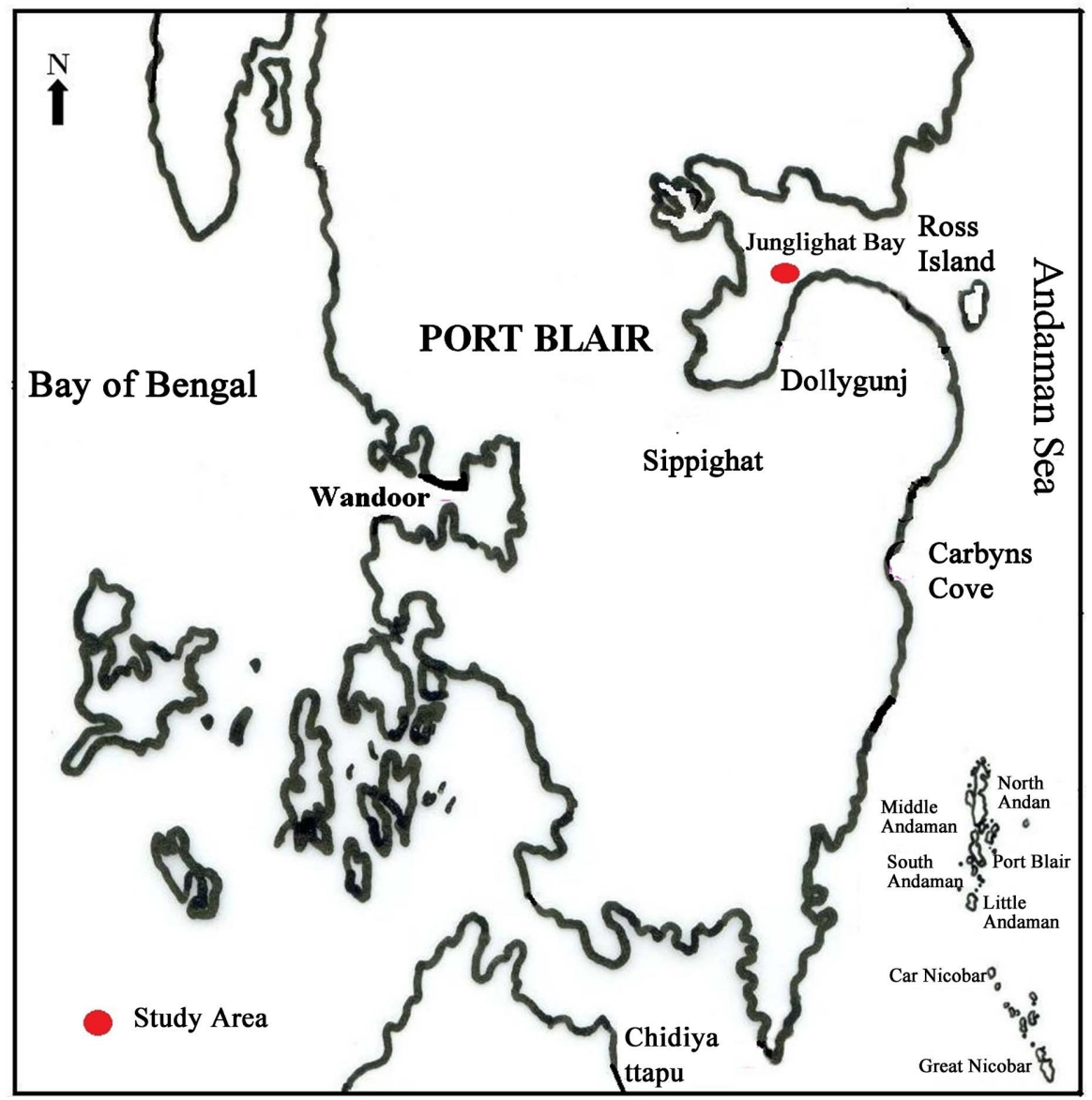

Figure 1. Sample collected location in the Junglighat Bay area, South Andaman, Andaman Islands, India.

preserved in the sample container. Later, the samples was photographed and identified using the different polychaeta keys, based on the morphological characters.

Location: Lat: $11^{\circ} 39^{\prime} 52.72 " \mathrm{~N}$; Long: $092^{\circ} 42^{\prime} 07.28^{\prime \prime} \mathrm{E}$-Off Junglighat, South Andaman, Andman Islands, India.

\section{Result}

\section{Systematics}

Family: Amphinomidae Lamark, 1818

Genus: Chloeia

Species: Chloeia flava pulchella Baird, 1868 (Figures 2(a)-(k))

Chloeia pulchella by Baird 1868, Vol. X, 1870, p.234.

Chloeia pulchella pallida Baird, 1868

Chloeia fiava, var. pulchella, by Horst 1912, p.19, pl.VII, Figure 3

\subsection{Description}

The collected single specimen was identified as a polychaeta, under the family Amphinomidae Lamark, 1818 (Figure 2). The sediment sample collected near 


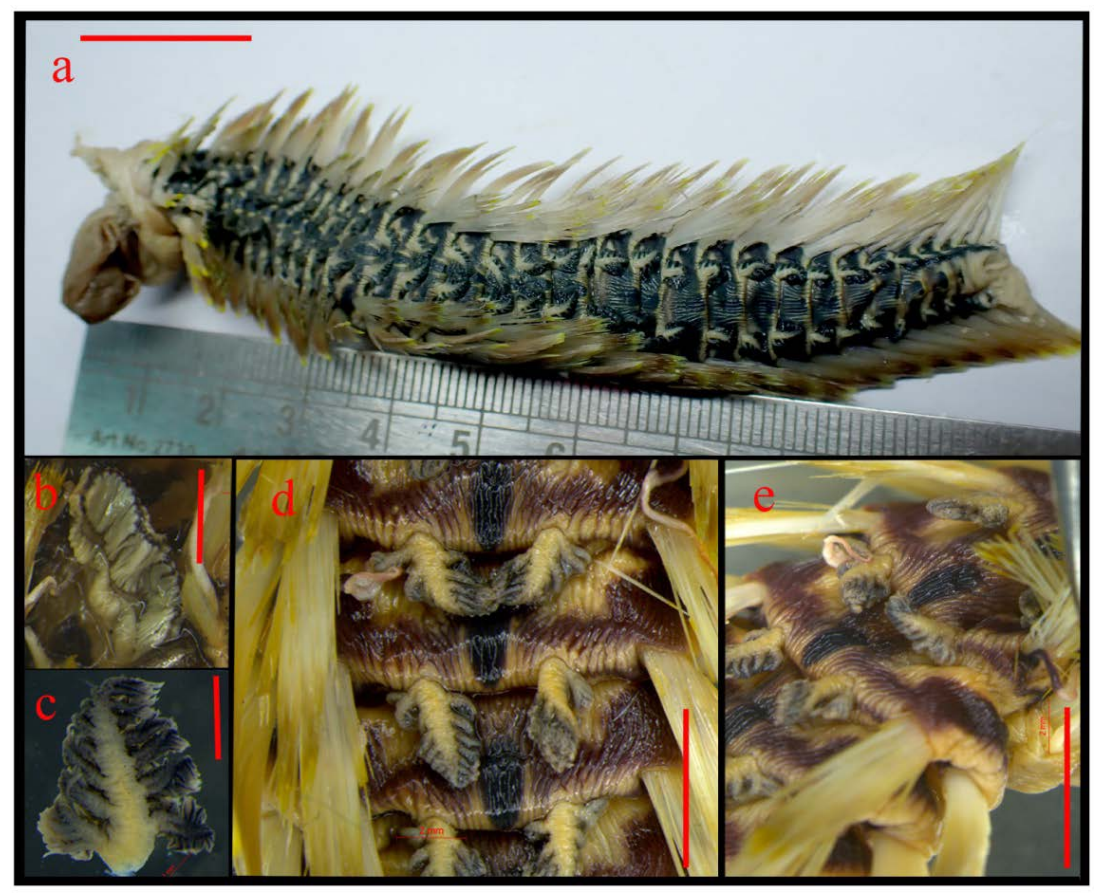

Figure 2. (a) Chloeia flava pulchella Barid 1868, (b) caruncle with a thin black border line, (c) branchia-dark greenish lateral brachlets, (d) dark eye shaped oval spots, (e) dark band over front side of each parapodia, scale bars: (a) $=20 \mathrm{~mm},(\mathrm{~b})=1 \mathrm{~mm},(\mathrm{c})=1 \mathrm{~mm}$, (d) $\&(e)=2 \mathrm{~mm}$.

Junglighat off shore environment in the South Andaman Island. The collected polychaeta was photographed and then preserved in $10 \%$ formalin. The dorsal markings were faded away from the specimen, when the photography was done. The fusiform body has 39 segments with a total length of $93.3 \mathrm{~mm}$ and 13.39 mm wide, without bristle.

Dorsal region was wrinkled and dark green in colour. The body bordered with light yellow color, around each dorsal dark narrow oval spots and towards the anterior and posterior edge of each chaeta. The mid dorsal region was marked with dark eye shaped oval spots on each segment, extending more than half from the posterior end to towards anterior side. The preserved specimen in formalin showed the dark green band of the chaeta over the front side of each parapodia, turned into purple. Ventral side was almost colorless with pinkish white or skin colour. The anterior portion of the head bears 4 pairs of eye and 4 pairs of antennae. The median antennae was little longer than the lateral ones. A medium sized caruncle showed a thin black border line, extending up to $4^{\text {th }}$ segment and anteriorely attached to the first two segments. A dark, undulating groove, running longitudinally, from anterior to posterior divides the caruncle into 2 unequal halves of lateral plicate plates.

On the dorsal surface, a pair of bipinnate branchia arranged on each segment from $4^{\text {th }}$ to $38^{\text {th }}$ segment, with a thick main axis of light yellowish color and 10 pairs of dark green colored lateral branchlets. The notopodal cirri showed with dark purple colour at the basal region and gradually become lighter towards the 
tip. The neuropodal cirri were seen as shorter than dorsal one and showing same colorations of ventral side. A pair of digitiform pygidial cirri of $3.8 \mathrm{~mm}$ in length were observed at posterior end.

Both notopodal and neuropodal setae were more or less equal in size. Length of setae varies from $5.59 \mathrm{~mm}$ at anterior, $11.60 \mathrm{~mm}$ at middle region and 9.84 $\mathrm{mm}$ at posteriorly. The color of the setae was white at the base and gradually becoming brownish towards the tip yellow in colour. Most of the noropodal setae was long, distally pointed with a series of harpoon shaped serration on one edge, except on the $3^{\text {rd }}$ to $7^{\text {th }}$ setae. The $39^{\text {th }}$ setae had a pronounced spur, observed opposite to the base of harpoon shaped serrations. The neuropodal setae were simple with smooth silky bifurcated apex.

\subsection{Remarks}

Unlike the previous reports of the Chloeia pulchella Barid 1868, this specimen had dark green in colour. The dorsal portion had longer with 39 segments. But the specimen clearly showing narrow dark eye shaped marking on the dorsal region as described by Barid [9]*. Like the description provided by Horst [10], this specimen was also showing longer slender dorsal cirri with very clear demarcation of dark purple coloration at the basal part. The setae of the specimen were much like the Chloeia flava just like the description given by other authors, but in this specimen a pronounced spur on the $3^{\text {rd }}$ to $7^{\text {th }}$ setae and also on the $39^{\text {th }}$ setae were clearly visible (Figure 3 ).

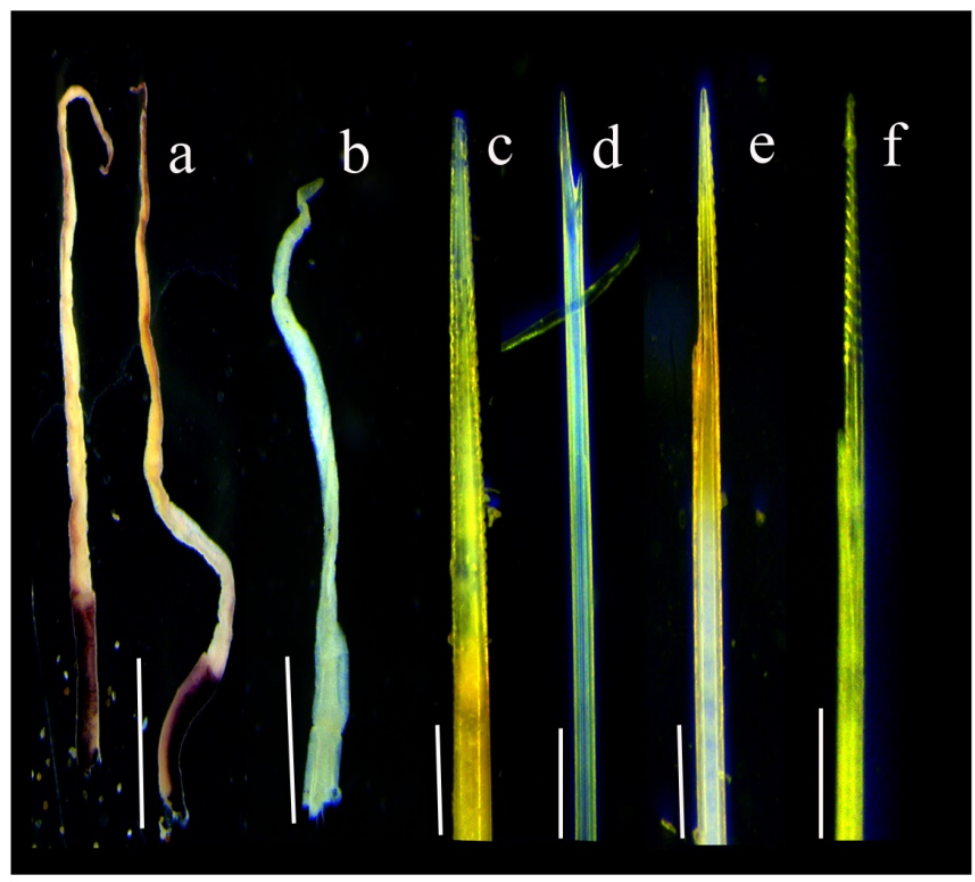

Figure 3. (a) Dorsal cirri with dark purple at the basal region, (b) ventral cirri, (c) notopodal harpoon setae, (d) neuropodal bifid setae, (e) notopodal setae of $3^{\text {rd }}$ to $7^{\text {th }}$ segment with a spur extension, (f) notopodal setae of $39^{\text {th }}$ segment. Scale bars: (a) \& (b) $=2 \mathrm{~mm}$; (c) $-(\mathrm{f})=200 \mu \mathrm{m}$. 


\section{Conclusion}

The collected polychaeta specimen was identified based on the above characters as Chloeia pulchella Barid 1868. The earlier reports showed that it was collected only from the Andaman Islands of India [1]. Now, 56 years after the first species was reported, the present species has been recorded from off Junglighat, in South Andaman, showing that there are still many unexploded areas in these groups of islands. The detailed study on each group of organism from unexplored parts of Andaman and Nicobar Island can bring much more new reports from these Islands

\section{Acknowledgments}

The authors are grateful to the authorities of the Department of Ocean Studies and Marine Biology of Pondicherry University for providing facilities to conduct this research work. The Ministry of Tribal Affairs, Government of India extended financial support as a fellowship to first author. The special thanks to the Administration of Andaman and Nicobar Island, and Department of Environment, Forests and Climatic Studies, New Delhi, to permit us to carry out the research project.

\section{Conflicts of Interest}

The authors declare no conflicts of interest regarding the publication of this paper.

\section{References}

[1] Hutchings, P.A. (2000) Family Ampharetidae. In: Beesley, P.L., Ross, G.J.B. and Glasby, C.J., Eds., Polychaetes \& Allies: The Southern Synthesis. Fauna of Australia, Polychaeta, Myzostomida, Pogonophora, Echiura, Sipuncula. CSIRO Publishing, Melbourne, 203-208.

[2] de León-González, J.A., Bastida-Zavala, J.R., Carrera-Parra, L.F., García-Garza, M.E., Peña-Rivera, A., Salazar-Vallejo, S.I. and Solís-Weiss, V. (2009) Poliquetos (Annelida: Polychaeta) de México y América Tropical. Universidad Autónoma de Nuevo León, Monterrey, México, p.737.

[3] Fauchald, K. and Jumars, P.A. (1979) The Diet of Worms: A Study of Polychaete Feeding Guilds. Oceanography Marine Biology Annual Review, 17, 193-284.

[4] Marsden, J.R. (1963) A Preliminary Report on Digestive Enzymes of Hermodice Carunculata. Canadian Journal of Zoology, 41, 159-164. https://doi.org/10.1139/z63-019

[5] Kudenov, J.D. (1995) Family Amphinomidae Lamarck, 1818. In: Blake, J.A., Hilbig, B. and Scott, P.H., Eds., Taxonomic Atlas of the Benthic Fauna of the Santa Maria Basin and Western Santa Barbara Channel, the Annelida. Part 2. Polychaeta: Phyllodocida (Sylliae and Scale-Bearing Families), Amphinomida and Eunicida. Santa Barbara Museum, Santa Barbara, 207-215.

[6] Read, G. and Fauchald, K. (2022) World Polychaeta Database. https://www.marinespecies.org/polychaeta/

[7] Sivadas, S.K. and Carvalho, R. (2020) Marine Annelida of India: Taxonomy and Status 
Evaluaton and an Updated Checklist. Journal of Threatened Taxa, 12, 16647-16714. https://doi.org/10.11609/jott.5357.12.12.16647-16714

[8] Tampi, P.R.S. and Rangarajan, K. (1964) Some Polychaetous Annelids from the Andaman Waters. Journal of Marine Biological Association of India, 6, 98-123.

[9] Baird, W. (1868) Contributions Towards a Monograph of the Species of Annelides Belonging to the Amphinomacea, with a List of the Known Species, and a Description of Several New Species (Belonging to the Group) Contained in the National Collection of the British Museum. To Which Is Appended a Short Account of Two Hitherto Nondescript Annulose Animals of a Larval Character. The Journal of the Linnean Society of London, Zoology, 10, 215-250.

https://biodiversitylibrary.org/page/31588091

https://doi.org/10.1111/j.1096-3642.1868.tb02233.x

[10] Horst, R. (1912) Polychaeta Errantia of the Siboga Expedition. Part1, Amphinomidae. Siboga-Expeditie Uitkomsten op Zoologisch, Bonatisch, Oceanographisch en Geologisch gebied verzameld in Nederlandsch Oost-Indië 1899-1900. V.24a, pp.1-43. https://biodiversitylibrary.org/page/2187401 